\title{
BOVALARS, CARNS I RAFALS: LA CASA DEL RAFALI' D'ALACANT
}

Por

MÁRIUS BEVIÀ

A l'Arxiu Municipal d'Alacant hi ha una interessant col.lecció de documents de les darreries del segle XVII i principis del XVIII que fa referència a la Casa del Rafali, les regestes de la qual, arreplegades en l'Index de Remissions de l'esmentat Arxiu, reproduim al final d'aquestes línies.

En aquesta col.lecció documental hom descriu una àrea, que podriem dir de serveis urbans, destinada al proveiment càrnic de la ciutat, de manera que es guardava la matèria primera dels carnissers - el caps de bestiar - que diàriament sacrificaven per liur venda al detall.

Aquesta àrea de serveis estava situada extramurs de la ciutat, a la vora del cami de l'Horta, on amb el temps es va desenvolupar el raval de Sant Antoni, en el carrer Corral de la Tria (1). Amb motiu de la guerra del Francés, i per a millorar la defensa de la ciutat, tota aquesta zona va ser derrocada, i posteriorment va ser remodelada; és per aixó que va desaparèixer tot record del conjunt que ara estudiem.

Aquest, estava format pel Bovalar, la casa del "Triero" i la casa del Rafall. El Bovalar, també anomenat Corral de la Tria, era un tancat on el ramat, propietat dels carnissers, podia pasturar fins el moment del seu sacrifici. Comptava amb un pastor, el triador, que tenia cura del bovalar i que, a partir d'un moment determinat, no podia vendre la carn dels animals morts, la carn de Rafalí, perquè aquesta passava a ser propietat de la ciutat, aixi com uns altres productes, como ora el fem o les despulles. Es per això que es va construir una casa pròpia, la Casa del Rafalí, perquè s'hi puguera vendre el producte, sota control de les arques municipals, als habitants de ciutat o als hostals, com ara "l'Hostal de la Balseta".

Tot i que la documentació referida al Bovalar d'Alacant és de les darreries del segle XVII, en la documentació medieval valenciana s'hi troba abundant informació sobre els bovalars. S'en parla de partides, tancats o deveses del terme d'una vila o un llogaret, generalment de seca, degudament delimitades o

(1) MARTINEZ MORELLA่ V., Nomenclátor de las vias públicas de Alicante en 1759, Alacant, 1954. 
amollonades, i reservades al pasturatge del bestiar de llaurança, a la dula i als animais dels carnissers de la població. Els podem trobar en els nuclis urbans importants, como ara, Castelló de la Plana, València, Xàtiva o Gandia (2). Amb toda probabilitat l'origen del de la nostra ciutat siga, també, de la mateixa època.

L'interés del topònim, Casa del Rafalí, rau en l'associació d'aquest mot, que ha estat viu fins temps relativament recents assimilat, a la llengua catalana parlada en les nostres terres, a unes altres paraulas relacionades amb funcions ramaderes periurbanes i urbanes, com són els bovalars.

Sabem que en l'àrab granadí, segons va recollir el vocabulista d'Alcalà (3), raha/l significa "carronya, cadàver d'animal". I la traducció lite ral'd'aquest mot ens diu que significa "guarda de ramat, pastor". La qual cosa concorda amb els documents suara esmentats. La carn morteîna, la carn de Rafalí, la carn de pastor, és aquella que ven el guarda del bovalar, del rafal musulmà. I així, possiblement, obtindria una ajuda al seu salari, pressumiblement curt, amb la relativa garantia d'oferir un producte més econòmic.

Amb aquestes línies hem pretés de fer una aportació, que considerem d'interés, al debat que sobre la societa t musulmana d'Al-Andalus s'està realitzant, tot reafirmant el caràcter pecuari dels rafals, ja estudiats per la doctora María Jesús Rubiera Mata en l'anterior número d'aquesta Revista (4).

Mexorar los capitulos. En 31 Octubre 1766 y baxo de otras fechas. Cabildos para que dos Rexidores y dos Diputados mexorasen y variasen en utilidad pública los capitulos del Abasto de carnes: lo que cumplieron y se aprovaron en los 24 Capitulos: se fixo el precio de los despojos; se designo del Bovalar que el abastecedor pudiera tener en el asta 10 cabezas; $y$ sobre triero y otros particulares.

Alm. 9, lib. 57, fols. $15,17$.

II

Carnicería del Rafali. En 20 Febrero de 1691. Sentencia de la Audiencia para que los Jurados designaran la Casa, eo, carneceria para vender fuera de la ciudad la carne de Rafalí.

Alm. 5, lib. 67, fols. 15, 17

III

Abasto Antiguo. En 31 Agosto 1691. Ordenes del Virrey e Informes de la Ciudad sobre ser anual el oficio de Fiel del Matadero, pago de su salario, el de

(2) COLÓN, G, y GARCiA, A., Furs de València. Llibre l, Rübrica ll. De les pástures e del vedat, Barcelona, 1970. REVEST CORzO, L., Ordinacions de la Vila de Castello de la Plana, Castelló, 1957 . Sobre el boular de Gandia. EE ARCHIVO, VI, 97

(3) DOZY, R. Supplément aux dictionnaires arabes, réimpression à Beirut, 1968, t. 1, p. 517.

(4) RUBIERA MATA. Maria Jesús, "Rał als y raales; ravals y arrabales; reals y reales", Sharq al-Andalus. Estudios árabes, 1, pp. 117-122 
sus cortantes, triero, corral, Casa del Rafall, y otros gastos, methodo de cobrar el Abasto con el partido, pieles, cuero, cabezas, pies y otros derechos en favor de la Ciudad y obligaciones del Fiel, y otros particulares. fol. 23

Alm. 11, lib. 21 , fols, 96,96 B; lib. 22, fol. 195; lib. 23 , fol. 83 ; lib. 24 ,

Boalar. Redonda. En 13 Agosto 1699. Orden del Virrey para que la Ciudad informara sobre si estavan limitados el Boalar y Redonda para el ganado de Abasto. Informó la Ciudad estavan demarcados segun lo capitulado en el arriendo de Abastos. Y insistio el Virrey remitiendo el memorial que causo esta instancia, manifestando los perjuicios que sentian los vecinos, y otros particulares que se expresavan.

Alm. 11, lib. 21, fols. 190, 213, 214; lib. 23, fols. 71, 72.

\section{V}

Ganado del Triero. En 2 Noviembre 1702 . Orden del Virrey, para que la Ciudad informara sobre haverse puesto a la venta de la carne mortesina, eo, de rafali en la casa del triero, y que este tenia ganado propio junto con el de Abasto. $Y$ que se destinara (Casa de Rafalin otra casa para venderse la carne mortesina. Informo la Ciudad tenia manda to que el trie ro no tuviera ganado alguno, y se buscaria otra casa para la venta de dicha carne. Y después reitero el Virrey que el triero no pudiera tener ganado propio ni llevarlo junto ni separado con el del Abasto porque no devia pastar las ierbas del Bovalar que eran propias del Abasto.

Alm. 11, lib. 28, fols. 209, 220.

\section{VI}

Rafali. En 26 Julio 1722 . Resolucion Capitular para que la carne mortecina, eo, de Rafalí se llevase en derechura a la casa del triero y de esta a la Carniceria destinada para vender lo justo al Mesón de la Balseta.

Alm. 9, lib. 12, fol. 143

VII

Corral de la Tria. En 21 Octubre 1721. Resolucion Capitular para que se compensaran las obras hechas por la Ciudad en el Corral de la Tria con los Alquileres que pretendia el triero $y$ se le dimitiera por averse disfrutado sin titulo de las turbaciones de la Guerra.

Alm. 9, lib. 11, fol. 1198 .

\section{VIII}

Carnicería del Raralí. En 20 Diciembre 1723. Resolucion Cap. para se pagaran las obras de la casa Carniceria del Rafalí.

Alm. 9, lib. 13, fol. 285. 